\title{
Naturaleza Predictiva de la Contabilidad y sus aplicaciones. Modelos de información contable prospectiva como evidencia
}

The Predictive Nature of Accounting. Predictive Accounting Systems and Models of Prospective Accounting Information as Evidence Natureza Preditiva da Contabilidade. Sistemas contábeis preditivos e modelos de informações contábeis prospectivas como evidência

\author{
Mónica Inés Aquistapace \\ Facultad de Ciencias Económicas, Univer- \\ sidad Nacional de Entre Ríos, Argentina \\ E-mail:miablanco@hotmail.com
}

Fecha de recepción: 01/11/2018 Fecha de aceptación: 20/06/2019

Palabras clave

- Contabilidad

- Carácter predictivo

- Teorías

- Sistemas contables

- Modelos contables

\section{Resumen}

El objetivo de este trabajo es reflexionar acerca de la naturaleza o carácter predictivo de la contabilidad como disciplina, que utiliza el método científico para su estudio e investigación. Además, este trabajo se propone analizar la importancia de los sistemas contables predictivos y de los modelos de información contable prospectiva, para confirmar ese carácter.

Para lograr el objetivo se inicia con el análisis de diferentes definiciones lo cual permite plantear hipótesis. Se trata de una investigación teórica, conceptual, que hace uso del método de la investigación jurídica (Pinto, 2011). Se reflexiona sobre el concepto de teorías en general y contables, continúa con una descripción sintética sobre la capacidad predictiva de algunas teorías, por un lado, y, por otro lado, los sistemas contables predictivos, incluido el sistema contable sugerido por el marco conceptual de las normas de información financiera (NIIF) en sus versión actual año 2018 y luego algunos modelos de contabilidad prospectivos. En el último apartado se analiza la influencia de la problemática epistemológica de la disciplina.

En las conclusiones lo más destacado se refiere al reconocimiento de teorías contables verificadas y comunicadas, las que en sus aplicaciones prácticas le otorgan carácter predictivo a las informaciones producidas por los sistemas contables. Ese carácter es previo a las posibilidades 
de proyección. Además, no es lo mismo sistemas contables predictivos que modelos de información contable prospectiva. Ambos surgen a partir de una metodología científica. Sin embargo, el sistema del actual marco conceptual 2018 induce a reflexionar que la predicción es más que una característica, es un requerimiento que merece ser atendido con mayores especificaciones. Finalmente, la tradición empírica otorga mayor estatus epistemológico a los estudios comprobados en las organizaciones, lo cual implica nuevos desafíos para próximas investigaciones.

\section{Abstract}

The purpose of this paper is to reflect upon the nature or predictive nature of Accounting as a discipline, whose study and research are conducted according to the scientific method. Furthermore, this article aims to analyze the importance of predictive accounting systems and of prospective accounting information models to confirm that predictive nature.

To achieve this objective, different definitions are analyzed first and some hypotheses are put forward. It is a theoretical, conceptual investigation that relies on the methodology for legal research (Pinto, 2011). It reflects upon the concept of theories in general and in Accounting; then, it continues with a concise description of the predictive capacity of some theories on the one hand and, on the other hand, the predictive accounting systems, including the accounting system suggested by the conceptual framework of the standards of financial information (IFRS) in its current version 2018. Moreover, it includes some prospective accounting models. In the last section, the influence of the epistemological problem of the discipline is analyzed.

Among the conclusions, the most outstanding refers to the recognition of verified and communicated accounting theories, which in their practical applications show the predictive nature of the information produced by the accounting systems. This characteristic is prior to the possibilities of projection. In addition, predictive accounting systems are not the same as prospective accounting information models, even though both stem from a

Keywords

- Accounting

- Predictive nature

- Theories

- Accounting systems

- Accounting models scientific methodology. However, the system of the current 2018 conceptual framework leads us to acknowledge that prediction is more than a characteristic: it is a requirement that must be met with greater specifications. Finally, the empirical tradition grants greater epistemological status to the proven studies in organizations, which implies new challenges for future research.

\section{Resumo}

0 objetivo deste trabalho é refletir sobre a natureza preditiva da contabilidade como disciplina, a que utiliza o método científico para seu estudo e pesquisa, assim como analisar a importância dos sistemas contábeis preditivos e dos modelos de informação contábel prospectiva, para confirmar essa natureza. 
Para atingir o objetivo começa-se com a análise de diferentes definições, 0 que permite formular hipóteses. Trata-se de uma investigação teórica, conceitual, que utiliza o método da pesquisa jurídica (Pinto, 2011). Reflete-se sobre 0 conceito de teorias em geral e contábeis, continua com uma breve descrição sobre a capacidade preditiva de algumas teorias por um lado, e, por outro, os sistemas contábeis de previsão, incluído o sistema de contabilidade sugerido pelo quadro conceitual de padrões de informações financeiras (IFRS) em sua versão atual de 2018 e, em seguida, alguns modelos contábeis prospectivos. No último ponto analisa-se a influência da problemática epistemológica da disciplina.

Nas conclusões, salienta-se o reconhecimento de teorias contábeis verificadas e comunicadas, as que, em suas aplicações práticas, conferem-Ihe caráter preditivo às informações produzidas pelos sistemas contábeis. Esse carácter é anterior às possibilidades de projeção. Aliás, não são 0 mesmo os sistemas contábeis preditivos do que os modelos prospectivos de informações contábeis. Ambos seriam a partir de uma metodologia científica.

Palavras-chave - Contabilidade

- Caráter preditivo

- Teorias

- Sistemas contábeis

- Modelos contábeis
Porém, 0 sistema do atual quadro conceitual 2018 leva a refletir que a previsão é mais do que uma característica, é uma exigência que merece ser atendida com maiores especificações. Por fim, a tradição empírica confere maior status epistemológico aos estudos comprovados nas organizações, 0 que implica novos desafios para futuras pesquisas. 